\title{
Induction of multiple immune regulatory pathways with differential impact in HCV/HIV coinfection
}

\author{
Hyosun Cho ${ }^{1,2,3}$, Masahiro Kikuchi ${ }^{1,2}$, Yun Li ${ }^{1,2}$, Nobuhiro Nakamoto ${ }^{1,2}$, Valerianna K. Amorosa ${ }^{1,2}$, \\ Mary E. Valiga ${ }^{1,2}$ and Kyong-Mi Chang ${ }^{1,2 *}$
}

1 Philadelphia VAMC, Philadelphia, PA, USA

2 Department of Medicine, University of Pennsylvania School of Medicine, Philadelphia, PA, USA

${ }^{3}$ Duksung Women's University, Seoul, South Korea

Edited by:

Lynn B. Dustin, University of Oxford,

UK

Reviewed by:

Kjetil Taskén, University of Oslo,

Norway

Georg Lauer, Massachusetts General

Hospital, USA; Harvard Medical

School, USA

*Correspondence:

Kyong-Mi Chang, Philade/phia VAMC, 3900 Woodland Avenue, Philadelphia PA 19104, USA

e-mail:kmchang@mail.med.upenn.

edu;kyong-mi.chang@va.gov
Persistent viral infections including $\mathrm{HCV}, \mathrm{HBV}$, and $\mathrm{HIV}$ are associated with increased immune regulatory pathways including the extrinsic FoxP3+CD4+ regulatoryT cells (Tregs) and intrinsic inhibitory pathways such as programed death-1 (PD-1) and cytotoxic T lymphocyte antigen-4 (CTLA-4) with potentially reversible suppression of antiviral effector T cells (1-12). Immunological consequences of viral coinfections relative to these immune regulatory pathways and their interplay are not well-defined. In this study, we examined the frequency, phenotype, and effector function of circulating $T$ cell subsets in patients with chronic HCV and/or HIV infection, hypothesizing that HCV/HIV coinfection will result in greater immune dysregulation with pathogenetic consequences $(13,14)$. We show that multiple T cell inhibitory pathways are induced in HCV/HIV coinfection including FoxP3+ Tregs, PD-1, and CTLA-4 in inverse association with overall CD4 T cell frequency but not with liver function or HCV RNA titers. The inverse association between CD4T cell frequency and their FoxP3, PD-1, or CTLA-4 expression remained significant in all subjects combined regardless of $\mathrm{HCV}$ and/or HIV infection, suggesting a global homeostatic mechanism to maintain immune regulation relative to $\mathrm{CD} 4 \mathrm{~T}$ cell frequency. PD-1 blockade rescued T cell responses to HIV but not HCV without significant impact by CTLA-4 blockade in vitro. Collectively, these findings highlight complex immune interactions in viral coinfections and differential regulatory pathways influencing virus-specific $T$ cells that are relevant in immunotherapeutic development.

Keywords: Tregs, PD-1, CTLA-4, immune pathogenesis, HCV, HIV, coinfection, FoxP3

\section{INTRODUCTION}

FoxP3+CD4 + regulatory T cells (FoxP3+ Tregs) play a key role in mediating immune tolerance to self and non-self antigens including viral pathogens (15). Programed death-1 (PD-1) and cytotoxic T lymphocyte antigen-4 (CTLA-4) are receptors in CD28 family of co-stimulatory molecules that are induced by $\mathrm{T}$ cell activation and provide inhibitory signals to T cells (16). There are further cross-talks between the "extrinsic" regulatory T cells (Tregs) and "intrinsic" $\mathrm{T}$ cell co-stimulatory pathways $(17,18)$. In chronic viral infection including $\mathrm{HCV}$, increased circulating frequency of CD4+FoxP3+ Tregs as well as increased PD-1 and/or CTLA-4 expression on virus-specific $\mathrm{T}$ cells have been reported $(6,7)$. Similarly, HIV persists with dysfunctional antiviral effector T cells with increased PD-1 and/or CTLA-4 expression $(3,19,20)$. HIV infection has also been associated with increased FoxP3+ Tregs in peripheral CD4 T cell compartment despite HIV-associated CD4 T cell loss in some (21-25) although not all studies (26-29). Furthermore, PD-1 and CTLA-4 expression in antiviral T cells correlated with HIV viral load and CD4 T cell count in HIV-monoinfected patients (3-5).

Further immune dysregulation may occur in HCV/HIV coinfection due to HCV-mediated immune activation and
HIV-associated CD4 T cell loss $(24,30)$. Such interactions may have clinical implications, given worsened outcomes in HCV/HIVcoinfected patients $(13,14)$. However, potential interplays between FoxP3+ Tregs and intrinsic $\mathrm{T}$ cell co-stimulatory pathways in viral infections have not been well-defined. Moreover, it remains unclear how they impact antiviral effector $\mathrm{T}$ cell response as well as HCV and/or HIV-associated outcomes. These are relevant considerations in immunotherapeutic development for chronic viral infection $(2-12,31)$ as well as cancer patients with concurrent viral infections (32).

In this study, we show that FoxP3+ Tregs are preserved in the CD4 T cell compartment of HCV/HIV-coinfected patients in direct association with PD-1 and CTLA-4 expression on CD4 $\mathrm{T}$ cells but not with liver function measures or HIV viremia. Furthermore, FoxP3, PD-1, CTLA-4, CD28, and CD127 expression showed significant associations with the overall CD4 T cell frequency, suggesting a global homeostatic mechanism to maintain immune regulation as the size of $\mathrm{CD} 4 \mathrm{~T}$ cell compartment changes. Finally, HIV-specific effector T cells were not only more detectable in peripheral blood and but also more responsive to PD-1 blockade in vitro, compared to HCV-specific $\mathrm{T}$ cells. 


\begin{tabular}{|c|c|c|c|c|}
\hline & $\begin{array}{c}\text { Chronic HCV } \\
\text { C } \\
n=20\end{array}$ & $\begin{array}{c}\text { Chronic HCV/HIV } \\
\text { I/C } \\
n=23\end{array}$ & $\begin{array}{c}\text { Chronic HIV } \\
\text { I } \\
n=21\end{array}$ & $\boldsymbol{P}$-values*** \\
\hline $\operatorname{Sex}(M: F)$ & $19: 1$ & $23: 1$ & $22: 0$ & NA \\
\hline Age (years)* & 55 & 55 & 48 & 0.13 \\
\hline SALT $(I U / m l)^{*}$ & 47 & 50 & 27 & $<0.0001$ \\
\hline Total bilirubin $(\mathrm{mg} / \mathrm{dl})^{*}$ & 0.7 & 1.0 & 0.7 & 0.16 \\
\hline Albumin $(g / d l)^{*}$ & 4.4 & 4.2 & 4.5 & 0.077 \\
\hline Platelets $\left(10^{3} / \mathrm{mm}^{3}\right)^{*}$ & 197 & 205 & 201 & 0.85 \\
\hline $\mathrm{INR}^{*}$ & 1 & 1 & 1 & 0.67 \\
\hline$A P R I^{*}$ & 0.6 & 0.6 & 0.3 & $<0.0001$ \\
\hline HCV genotype 1 (\%) & $85 \%$ & $96 \%$ & NA & NA \\
\hline median HCV RNA (IU/ml) & $2,750,000$ & $1,210,000$ & NA & 0.98 \\
\hline HAART & NA & $87 \%$ & $95 \%$ & 0.61 \\
\hline Time from HIV diagnosis* & NA & 13 years & 12 years & 0.75 \\
\hline HIV viral load $<50$ & NA & $83 \%$ & $61 \%$ & 0.1 \\
\hline CD4 count ${ }^{* *}$ & NA & 407 & 586 & 0.043 \\
\hline
\end{tabular}

*Median values.

* ${ }^{*}$ CD4 count in 16 HCV/HIV and 15 HIV patients peformed within 1 month of immune analyses among HIV-infected patients.

***P-values by non-parametric Kruskal-Wallis for three groups and Mann-Whitney $U$ for two groups.

NA (not applicable).

\section{MATERIALS AND METHODS STUDY SUBJECTS}

Study subjects were recruited from the Hepatology and Infectious Diseases clinics in the Philadelphia Veterans Affairs Medical Center and the Hospital of the University of Pennsylvania with informed consent approved by the institutional review board: HCV-monoinfection (HCV, $n=20$ ), chronic HCV/HIV coinfection (HCV/HIV, $n=23$ ), chronic HIV-monoinfection (HIV, $n=21$ ), and seronegative controls (NC, $n=17$ ). Exclusion criteria included: active immunosuppressive therapy, active antiviral therapy for HCV infection, HBV infection, autoimmune liver disease, or significant medical comorbidities that preclude blood draws or informed consent. Chronic HCV infection was defined by persistent HCV viremia by quantitative RT-PCR by Roche COBAS or TaqMan assays (Roche Diagnostics, Indianapolis, IN, USA) in HCV-seropositive persons without acute hepatitis. HIV infection was defined by detection of HIV Ab and/or HIV viral load. As shown in Table 1, most patients were males in their 50s consistent with our local patient population. Clinical liver-associated parameters (e.g., bilirubin, albumin, platelet count, prothrombin time INR, AST Platelet Ratio Index APRI) were largely preserved, although sALT activity was greater in HCV and HCV/HIV groups compared to HIV-monoinfected group. Majority of HIV-infected patients were on anti-retroviral therapy and displayed HIV viral load below $50 \mathrm{IU} / \mathrm{ml}$.

\section{ISOLATION OF PERIPHERAL BLOOD MONONUCLEAR CELLS}

Peripheral blood mononuclear cell (PBMC) were isolated by Ficoll-Histopaque (Sigma Chemical Co., St Louis, MO, USA) density centrifugation and used directly or cryopreserved as previously described (33).

\section{PEPTIDES AND HLA CLASS I TETRAMERS}

HCV-specific $\mathrm{T}$ cell response was measured using a pool of 105 overlapping $15 \mathrm{mer}$ peptides spanning the entire HCV NS3 derived from HCV-H genotype 1a (34). HIV-specific T cell response was measured using a pool of 124 overlapping $15 \mathrm{mer}$ peptides spanning the entire HIV Gag (generously provided by the AIDS Research and Reference Reagent Program, Division of AIDS, NIAID, NIH) (35). T cell response to influenza virus was examined using 56 overlapping 15 mer peptides spanning the conserved matrix M1 protein (residues 1-252) based on the human A/PR/8/34 (H1N1) virus. For HLA-A2+ subjects, the following peptides were synthesized for antigenic stimulation and tetramer synthesis as described previously $(6,7)$ : (i) HCV NS3 1073 (CINGVCWTV), NS3 1406 (KLVALGINAV), and NS5B 2594 (ALYDVVSKL); (ii) HIV Gag (SLYNTVATL); (iii) influenza matrix (GILGFVFTL); (iv) EBV BMLF1 (GLCTLVAML); (v) CMV pp65 (NLVPMVATV).

\section{FLUORESCENT ANTIBODIES}

All monoclonal antibodies were purchased from BD Bioscience (San Jose, CA, USA) except for anti-Foxp3 from eBioscience (San Diego, CA, USA). Foxp3 and CTLA-4 expression was examined using FITC-labeled $\alpha$ Foxp3 (clone PCH101, eBioscience) and PElabeled $\alpha$ CTLA-4 ( $\alpha$ CD152; clone BNI3, BD). Dead cells were excluded with 7AAD.

\section{IMMUNOPHENOTYPING BY FLOW CYTOMETRY}

Cells were stained by fluorescent antibodies as per manufacturer's instructions with freshly isolated PBMC used directly ex vivo (36). Events were acquired with a FACSCanto (Becton Dickinson, San Jose, CA, USA) and analyzed with FlowJo (Tree Star Inc., Ashland, OR, USA), gating on live lymphoid cells based on scatter 
characteristics and viability staining (7AAD by Biolegend or Aqua LIVE/DEAD L34957 by Invitrogen) and single color compensation controls. Intracellular FoxP3 and CTLA-4 expression was detected after permeabilization with cutoffs determined by isotype controls (Foxp3: 99.9\%, CTLA-4: 99.9\%) as previously described $(6,36)$.

The frequency of FoxP3+CD4+ Tregs (\%Foxp3+CD4+/ lymphocytes) in total lymphocytes was measured as percentage of FoxP3+CD4+ T cells in live lymphocyte gate. FoxP3+ Treg frequency in CD4 T cells (\%FoxP3+/CD4 T cells) was measured as percentage of FoxP3 + cells within CD4+ live lymphocytes. Similar strategies were used to define circulating frequency of CD4+ or CD8 + T cells expressing PD-1, CTLA-4, or CD28+ T cells in total, CD4+ or CD8+ live lymphocytes.

\section{ANALYSIS OF VIRUS-SPECIFIC T CELL IFN $\gamma$ AND TNF $\alpha$ PRODUCTION IN SHORT TERM T CELL LINE}

PBL $\left(2 \times 10^{6}\right.$ cells $/ \mathrm{ml} /$ well in 24 -well plate $)$ were: (1) stimulated with media, overlapping 15mer peptide pools (HCV NS3, HIV Gag, or influenza matrix at $2 \mathrm{iM}$ per peptide) on day 0 ; (2) supplemented by fresh media with rIL-2 $(100 \mathrm{IU} / \mathrm{ml})$ on day 3 or 4 ; (3) examined by antigen-specific TNF $\alpha$ and IFN $\gamma$ production on day 7 by intracellular cytokine staining as previously described (7).

\section{ANALYSIS OF ANTIGEN-SPECIFIC T CELL EXPANSION AND EFFECTOR FUNCTION IN THE PRESENCE OR ABSENCE OF PD-1 AND/OR CTLA-4 BLOCKADE}

PBL $\left(2 \times 10^{6}\right.$ cells $/ \mathrm{ml} /$ well in 24 -well plate $)$ were stimulated with overlapping HCV NS3, HIV Gag, or influenza matrix 15mer peptide pools $(2 \mu \mathrm{M})$ in the presence of isotype control, aPD-L1 (clone 29E.2A3.C6), aCTLA-4 (clone BNI3; BD), or both aPD-L1 and aCTLA-4 $(10 \mu \mathrm{g} / \mathrm{ml}$ for each $\mathrm{mAb})$ as previously described (7). Cell cultures were stimulated with rIL-2 $(100 \mathrm{IU} / \mathrm{ml})$ on day 3 or 4 and examined for cytokine production by flow cytometry on day 7 after $6 \mathrm{~h}$ stimulation with and without HCV, HIV, or Flu peptides in the presence of brefeldin A $(10 \mu \mathrm{g} / \mathrm{ml})$ as previously described (7). Virus-specific responses were calculated by subtracting the cytokine responses in media control samples from peptide-stimulated samples during the intracellular cytokine staining. A positive response to blockade was defined as antigenspecific response that was greater than the isotype control condition by at least a standard deviation of the all background responses $(0.36 \%)$.

\section{CYTOKINE ANALYSIS OF FoxP3+ AND FoxP3- T CELLS IN PBMC EX VIVO}

PBL $\left(2 \times 10^{6}\right.$ cells $/ \mathrm{ml} /$ well in 24 -well plate $)$ were stimulated with or without overlapping HCV NS3, HIV Gag, influenza matrix 15 mer peptide pools $(2 \mu \mathrm{M})$ or $10 \mathrm{ng} / \mathrm{ml}$ phorbol 12 -myristate 13-acetate (PMA; Sigma Chemical Co.), $200 \mathrm{ng} / \mathrm{ml}$ ionomycin (Sigma Chemical Co.) in the presence of brefeldin A $(10 \mu \mathrm{g} / \mathrm{ml})$ and FoxP3, and intracellular cytokine staining was performed after $5.5 \mathrm{~h}$ with a Cytofix/Cytoperm kit (BD Pharmingen) as previously described (36).

\section{IFN $\gamma$ ELISPOT ASSAY}

IFN $\gamma$ Elispot assays were performed with 200,000 PBMCs per well stimulated in triplicates by overlapping pHCV NS3, pHIV
Gag, or pFlu matrix 15 mer peptide pools $(2 \mathrm{mM})$ or media alone. After $45 \mathrm{~h}$, plates were developed and IFNg spot forming units (SFUs) counted by an ELISPOT reader as previously described (37). Antigen-specific IFNg + T cells were quantified by subtracting the mean IFNg SFUs in negative control wells from the mean SFUs in antigen-stimulated wells and expressed as IFN $\gamma$ SFUs $/ 10^{6}$ cells. A response was considered positive if it was above the cutoff value calculated from negative control wells as average mean SFU +3 standard deviations ( 57 SFUs $/ 10^{6}$ cells).

\section{CELL SORTING}

$\mathrm{CD} 4+\mathrm{CD} 25+$ and $\mathrm{CD} 4+\mathrm{CD} 25-$ subsets were sorted by autoMACS using the CD4+CD25+ regulatory $\mathrm{T}$ cell isolation system (Miltenyi Biotec Inc., Auburn, CA, USA) as previously described (36). FoxP3 expression in sorted CD4+CD25+ and CD4+CD25- T cell subsets was determined by FACS to compare direct FoxP3 + Treg frequency and effector T cell suppression in subsequent ex vivo Treg suppression assay.

\section{EX VIVO Treg SUPPRESSION ASSAY}

AutoMACS-sorted CD4+CD25+: "suppressor" T cells were cocultured in triplicate wells with autologous CD4+CD25- "responders" (60,000 cells/well) in 96-well plates at suppressor/responder ratios of 1:0,1:1, 0.5:1, 0.25:1,0.125:1, and 0:1 for 3 days with media alone, $2 \mu \mathrm{g} / \mathrm{ml}$ phytohemagglutinin (PHA; Sigma Chemical Co.), or $0.04 \mu \mathrm{g} / \mathrm{ml}$ anti-CD3 (clone UCHT1; BD Pharmingen) with $2 \mu \mathrm{g} / \mathrm{ml}$ anti-CD28 (clone CD28.2; BD Pharmingen) before $16 \mathrm{~h}$ of $[3 \mathrm{H}]$ thymidine $(1 \mu \mathrm{Ci} /$ well $)$ uptake as previously described $(7$, $33,36)$. Proliferation was expressed as a stimulation index (SI): the mean cpm in stimulated wells divided by the mean cpm in unstimulated wells. T cell proliferation in each coculture was normalized by proliferation in CD4+CD25- T cells alone and compared to the calculated percentage of FoxP3+CD4 T cells in each coculture condition, based on \%FoxP3 + cells in CD4+CD25- and CD4+CD25+ cell subsets determined by FACS.

\section{STATISTICAL ANALYSIS}

Clinical and immunologic parameters between patient groups were compared by the non-parametric Mann-Whitney $U$ test or Kruskal-Wallis. With multiple two-way comparisons, $P$-values were corrected for multiple comparisons. Pair-wise comparisons were performed by paired $t$-test. Correlations were tested for statistical significance by Spearman rank correlation. $P$-values below 0.05 were considered significant.

\section{RESULTS}

\section{FOXP3 EXPRESSION IS INCREASED IN CD4 T CELLS FROM} HCV/HIV-COINFECTED THAN HIV OR HCV-MONOINFECTED PATIENTS

Table 1 shows the demographic, clinical, and virological characteristics of our patient groups with $\mathrm{HCV}(n=20), \mathrm{HCV} / \mathrm{HIV}$ $(n=23)$, and HIV $(n=21)$ infection. They were mostly males in their 50s with preserved liver function (e.g., serum albumin, total bilirubin, INR, and platelets). Majority of HCV-infected patients had HCV genotype 1 infection, without significant differences in HCV RNA titers between HCV and HCV/HIV groups $(P=0.98)$, consistent with previous findings from our population (13). HIV viral load was undetectable in $83 \%$ in HCV/HIV-coinfected and in $61 \%$ in HIV-monoinfected patients $(P=0.10)$. 


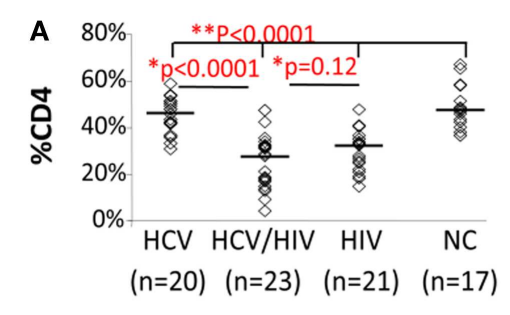

C
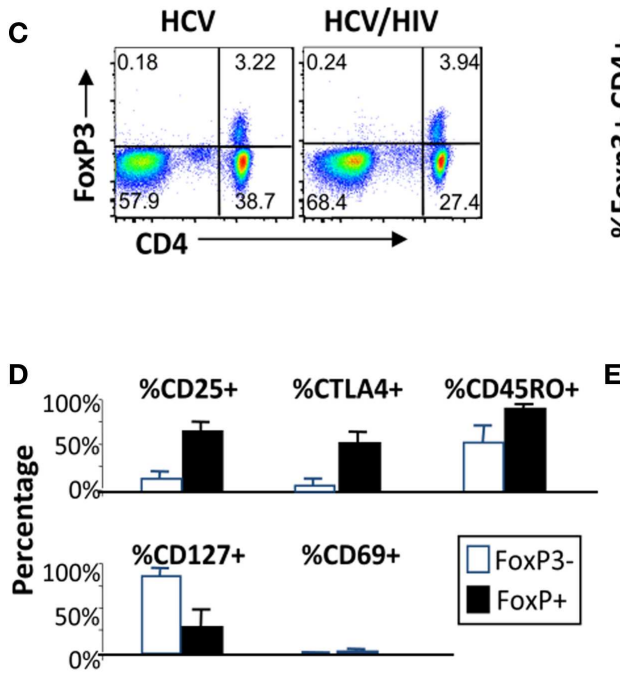

B
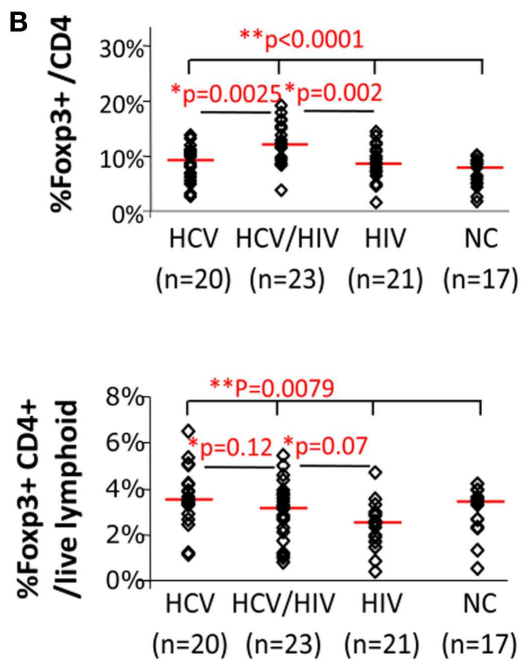

$\mathbf{E}$

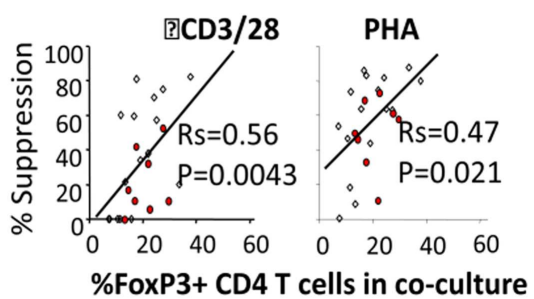

FIGURE 1 | FoxP3+ Tregs are enriched in CD4 T cells from HCV/HIV-coinfected patients. (A) Frequency of CD4T cells among viable lymphocytes is compared between $20 \mathrm{HCV}$-monoinfected (HCV), 23 HCV/HIV-coinfected (HCV/HIV), 21 HIV-monoinfected (HIV), and 17 seronegative control (NC) subjects. Horizontal bars indicate median values. $P$-values are calculated with non-parametric Kruskal-Wallis for comparison between all four groups and Mann-Whitney $U$ for pair-wise comparisons. Two-way comparison of HCV/HIV coinfection group with HCV or HIV-monoinfection group was made using non-parametric Mann-Whitney $U$ and corrected for multiple comparisons. (B) Frequency of FoxP3+CD4T cells (FoxP3+ Tregs) in CD4 T cells is compared between $20 \mathrm{HCV}$-monoinfected (HCV), 23 HCV/HIV-coinfected (HCV/HIV), 21 HIV-monoinfected (HIV), and 17 seronegative control (NC) subjects. Horizontal bars indicate median values. $P$-values are calculated with non-parametric Kruskal-Wallis for comparison between all four groups and Mann-Whitney $U$ for pair-wise comparisons. Two-way comparison of HCV/HIV coinfection group with HCV or HIV monoinfection group was made using non-parametric Mann-Whitney $U$ and corrected for multiple comparisons. (C) Left panel: representative FACS plots are shown for FoxP3 and CD4 expression in live lymphocytes: Right panel: frequency of FoxP3+CD4+T cells in total live lymphoid cells is compared between $20 \mathrm{HCV}$-monoinfected (HCV), 23 HCV/HIV-coinfected (HCV/HIV), 21 HIV-monoinfected (HIV), and 17 seronegative control (NC) subjects. Horizontal bars indicate median values. $P$-values are calculated with non-parametric Kruskal-Wallis for comparison between all four groups and Mann-Whitney $U$ for pair-wise comparisons. Two-way comparison of HCV/HIV coinfection group with HCV or HIV monoinfection group was made using non-parametric Mann-Whitney $U$ and corrected for multiple comparisons. (D) Phenotype of FoxP3+CD4 T cells (filled black bars) and FoxP3- CD4T cells (unfilled bars) from HCV/HIV-coinfected patients are compared using percentage of cells expressing CD25, CTLA-4, CD45RO, CD127, and CD69. (E) Percent suppression of proliferation in AutoMACS-sorted CD4+CD25 - "responder" T cells alone and with increasing proportion of autologous CD4+CD25+ "suppressor" T cells enriched for FoxP3+CD4 T cells upon in vitro stimulation with anti-CD3/CD28 or phytohemagglutinin (PHA) followed by $3 \mathrm{H}$ thymidine uptake. Proliferation was expressed as a stimulation index (SI): the mean cpm in stimulated wells divided by the mean $\mathrm{cpm}$ in unstimulated wells. T cell proliferation in each coculture was normalized by proliferation in CD4+CD25T cells alone and compared to the calculated percentage of FoxP3+CD4 $T$ cells in each coculture condition, based on \%FoxP3+ cells in CD4+CD25and $\mathrm{CD} 4+\mathrm{CD} 25+$ cell subsets determined by FACS
We began by examining CD4 T cells for overall frequency and FoxP3 expression. As expected, CD4 T cell frequency was lower in HIV-infected subjects compared to HIV-uninfected subjects, without a significant difference between HCV/HIV-coinfected and HIV-monoinfected patients $(P=0.12)$ (Figure 1A). Notably, FoxP3 expression was enriched in CD4 T cells from HCV/HIVcoinfected patients both in frequency (HCV $8.9 \%$ vs. HCV/HIV $11.9 \%$ vs. HIV $8.5 \%$ vs. NC $7.5 \%, P<0.0001$ ) (Figure 1B) and mean fluorescence intensity (MFI) (Figure S1 in Supplementary Material) compared to other groups. Accordingly, FoxP3+CD4+ $\mathrm{T}$ cell frequency in the lymphocyte compartment was preserved in
HCV/HIV-coinfected patients compared to HCV-monoinfected patients (3.2 vs. $3.5 \%, P=0.12)$ despite lower $\mathrm{CD} 4 \mathrm{~T}$ cell frequency (Figure 1C). FoxP3+CD4+ T cells from HCV/HIVcoinfected patients resembled natural Tregs with increased CD25, CTLA-4, and CD45RO expression and reduced CD127 and CD69 expression (Figure 1D) as well as dose-dependent suppression of $\mathrm{CD} 4+\mathrm{CD} 25-\mathrm{T}$ cell proliferation in vitro (Figure 1E) as previously described for HCV-monoinfected patients (36). Thus, HCV/HIV coinfection was associated with an enrichment of FoxP3 + subsets within the CD4 $\mathrm{T}$ cell compartment and relative preservation of FoxP3+ Tregs in circulating lymphocytes. 
A
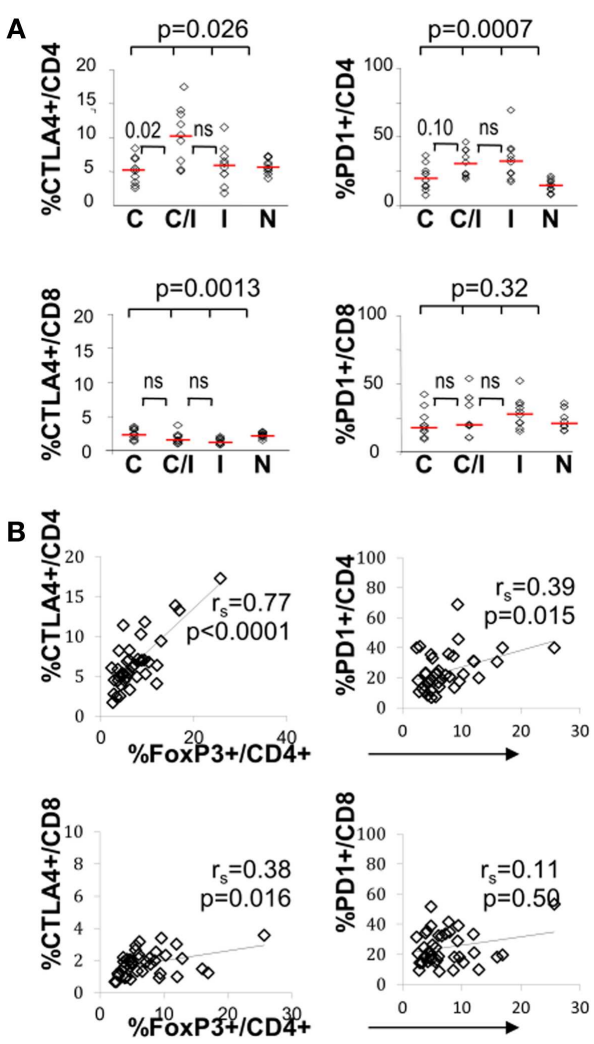

FIGURE 2 |T cell expression levels of PD-1 and/or CTLA-4 associate with FoxP3+ Tregs in patients with HCV and/or HIV infection. (A) Frequency of CD4 and CD8 T cells expressing CTLA-4, PD-1, CD28, or CD127 are compared between $10 \mathrm{HCV}$-monoinfected (C), $9 \mathrm{HCV} / \mathrm{HIV}$-coinfected (C/I), 10

HIV-monoinfected (I), and 10 seronegative control subjects (N). Horizontal bars indicate median values. $P$-values are calculated with non-parametric Kruskal-Wallis for comparison between all four groups. Two-way comparison

\section{T CELLS FROM HIV/HCV-COINFECTED PATIENTS DISPLAY DYSREGULATED EXPRESSION OF INTRINSIC T CELL CO-STIMULATORY RECEPTORS IN ASSOCIATION WITH FOXP3+ Treg FREOUENCY}

The effect of differential FoxP3 + Treg enrichment on intrinsic T cell inhibitory (CTLA-4, PD-1) and co-stimulatory (CD28 and $\mathrm{CD} 127$ ) receptors was further examined in a subset of subjects with available lymphocytes. As shown in Figure $\mathbf{2 A}$ and Table 2, there were significant phenotypic differences in $\mathrm{T}$ cell subsets from the patient groups relative to HCV and/or HIV infection. First, CTLA4 expression in $\mathrm{CD} 4 \mathrm{~T}$ cells resembled FoxP3 in that it was highest in $\mathrm{HCV} / \mathrm{HIV}$-coinfected patients compared to other groups. Second, expression levels of PD-1, CD28, and CD127 in CD4 T cells were largely linked to HIV infection. For example, CD4 T cells in $\mathrm{HCV} / \mathrm{HIV}$-coinfected and HIV-monoinfected patients displayed PD-1 expression at twofold higher level compared to CD4 T cells from HIV-uninfected patients (Table 2). Furthermore, CD4 T cells from HCV/HIV-coinfected and HIV-monoinfected patients displayed more subtle but significantly lower CD28/CD127 expression compared to CD4 T cells from HIV-uninfected patients. Third, CTLA-4, CD28, and CD127 expression levels in CD8 T cells were significantly lower in HIV-infected than in HIV-uninfected patients. Finally, FoxP3 + Treg frequency correlated directly with
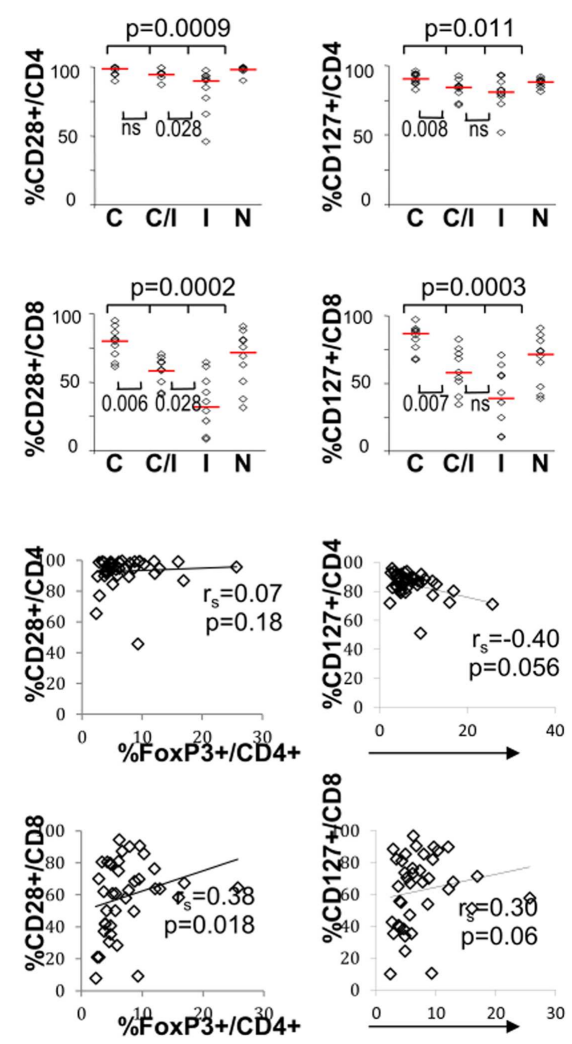

of HCV/HIV coinfection group with HCV or HIV monoinfection group was made using non-parametric Mann-Whitney $U$ and corrected for multiple comparisons. P-values above 0.05 before correction are shown as "ns" or "not significant." (B) Frequency of CD4 and CD8T cells expressing CTLA-4, PD-1, CD28, or CD127 are correlated with FoxP3+ Treg frequency in the CD4 $T$ cell compartment, with non-parametric Spearman rank-order correlation and $P$-values.

CTLA-4 expression in CD4 T cells as expected (Figure 2B) but also with PD-1 expression in CD4 T cells as well as CTLA-4 and CD28 expression in CD8 T cells (Figure 2B).

We further examined expression of PD-1 and CTLA-4 in FoxP3+ Tregs. As shown in Figure 3, PD-1 expression differed significantly between the four patient groups, without significant differences for CTLA-4. There was no significant difference between the groups in CD28 or CD127 expression in FoxP3+ Tregs (data not shown). Differential PD-1 expression by FoxP3+ Tregs was based on HIV infection, as FoxP3+ Tregs displayed twofold higher PD-1 expression than FoxP3+ Tregs from HIV-infected patients (44 vs. $28 \%, P=0.0017$ ) (Table 2). Thus, HCV/HIV coinfection was associated with global dysregulation in $\mathrm{T}$ cell phenotype in association with FoxP3 + Treg frequency, with both HCV and HIV-mediated effects.

\section{FoxP3+ Treg FREQUENCY AND GLOBAL T CELL EXPRESSION OF INTRINSIC CO-STIMULATORY RECEPTORS CORRELATE WITH CD4 T CELL FREOUENCY}

Inverse association between FoxP3+ Treg frequency and CD4 $\mathrm{T}$ cell frequency was previously reported in HIV-monoinfected patients (23). In our study, inverse correlation between FoxP3+ 
Table 2 | Phenotype comparison of CD4 and CD8T cells from HIV + and HIV- subjects.

\begin{tabular}{|c|c|c|c|c|c|}
\hline & \multicolumn{2}{|c|}{ HIV+ } & \multicolumn{2}{|c|}{ HIV- } & \multirow[b]{2}{*}{${ }^{*} \boldsymbol{P}$-valu } \\
\hline & Median & SD & Median & SD & \\
\hline \multicolumn{6}{|c|}{ A. CD4T CELLS } \\
\hline$\%$ PD1+ & 30.9 & 7.6 & 15.9 & 12.8 & 0.0001 \\
\hline \% CTLA4+ & 6.5 & 1.6 & 5.3 & 4.1 & 0.06 \\
\hline$\%$ CD28+ & 93.3 & 3 & 98.8 & 13.1 & 0.0005 \\
\hline$\% C D 127+$ & 82.5 & 3.9 & 88.7 & 9.8 & 0.0024 \\
\hline \multicolumn{6}{|c|}{ B. CDST CELLS } \\
\hline 0/0PDI+ & 26.2 & 9 & 18.5 & 12.8 & 0.112 \\
\hline$\%$ CTLA4+ & 1.2 & 0.6 & 2.2 & 0.7 & 0.0003 \\
\hline$\% \mathrm{CD} 28+$ & 49.6 & 17.3 & 77.8 & 19.8 & 0.0001 \\
\hline <VoCD127+ & 53.9 & 16.8 & 78.8 & 20.8 & 0.0003 \\
\hline \multicolumn{6}{|c|}{ C. FoxP3+CD4+T CELLS } \\
\hline$\%$ PD1+ & 44 & 9.7 & 28 & 12.3 & 0.0017 \\
\hline \% CTLA4+ & 53 & 12.6 & 50 & 10.7 & 0.98 \\
\hline$\% \mathrm{CD} 28+$ & 98 & 0.9 & 99 & 8.9 & 0.06 \\
\hline$\% \mathrm{CD} 127+$ & 25 & 15.2 & 20 & 11.6 & 0.81 \\
\hline
\end{tabular}

*P-values by non-parametric Mann-Whitney U.

$S D$, standard deviation.

Treg and CD4 $\mathrm{T}$ cell frequencies was also seen in HCV/HIVcoinfected patients as well as HIV-monoinfected patients (Figure 4A). This correlation became even stronger when results from all groups including uninfected controls were combined (Figures 4A,B far right). However, FoxP3+ Treg frequencies remained higher in HCV/HIV-coinfected than HIV-monoinfected patients in a subgroup analysis with lower or higher CD4 T cell frequencies based on a median cutoff (31\%) (Figure 4C). This difference was also visually apparent by higher clustering of data points from HCV/HIV-coinfected patients on the $y$-axis (red diamonds) compared to those from HIV-monoinfected patients (blue triangles) (far right graph on Figure 4A).

Nevertheless, FoxP3+ Treg frequency in total lymphocytes decreased as overall CD4 T cell frequency declined (Figure 4D). Finally, global CTLA-4 and PD- 1 expression in CD4 but not CD8 T cells correlated inversely with overall $\mathrm{CD} 4 \mathrm{~T}$ cell frequency whereas CD28 and CD127 expression in both CD4 and CD8 T cells correlated directly with $\mathrm{CD} 4 \mathrm{~T}$ cell frequency (Figure $4 \mathrm{E}$ ). Thus, FoxP3+ Treg frequency was significantly associated with CD4 T cell frequency, which was further linked to $\mathrm{T}$ cell expression of multiple inhibitory and co-stimulatory receptors.

\section{FOXP3 EXPRESSION IN CD4 T CELLS IS NOT ASSOCIATED WITH LIVER FUNCTION PARAMETERS OR LEVEL OF HIV/HCV VIREMIA}

Despite its significant associations with CD4 $\mathrm{T}$ cell frequency and global $\mathrm{T}$ cell phenotype, FoxP3+ Treg frequency did not correlate with serum HCV RNA titers or liver function parameters (Figure S2A in Supplementary Material). Similarly, T cell expression of PD-1, CTLA-4, or CD28 did not correlate with HCV RNA titers or clinical liver function parameters (data not shown). As previously reported (38-41), age was positively associated with FoxP3+ Treg frequency (Figure S2B in
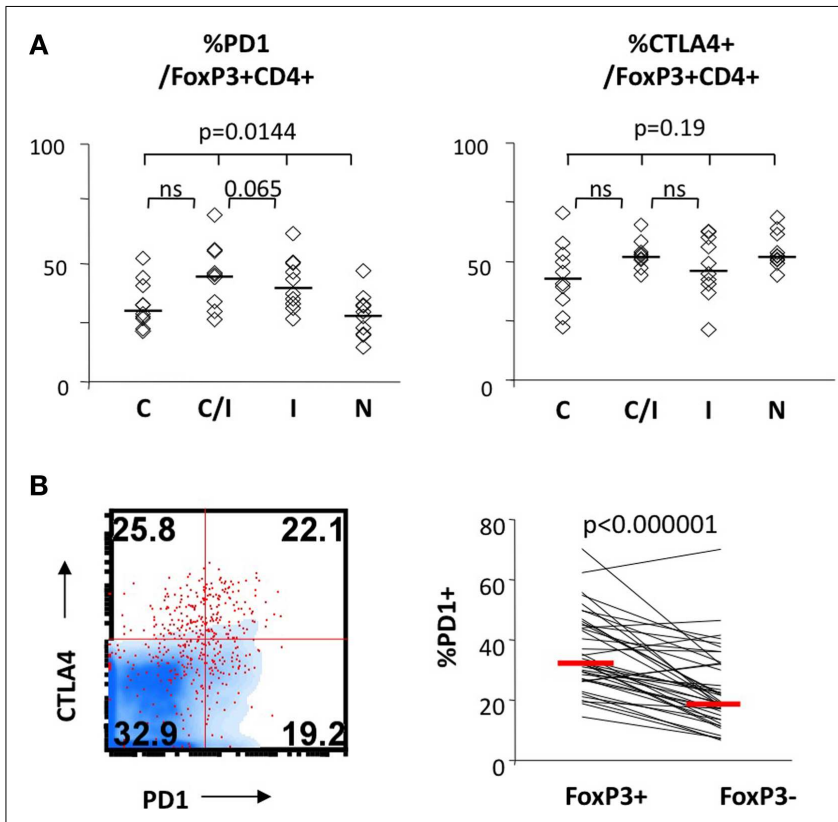

FIGURE 3 | FoxP3+ Treg expression levels of PD-1 and/or CTLA-4 in patients with HCV and/or HIV infection. (A) Frequency of FoxP3+Tregs expressing CTLA-4 and PD-1 are compared between $10 \mathrm{HCV}$-monoinfected (C), $9 \mathrm{HCV} / \mathrm{HIV}$-coinfected (C/I), $10 \mathrm{HIV-monoinfected} \mathrm{(I),} \mathrm{and} 10$ seronegative control subjects $(N)$. Horizontal bars indicate median values. $P$-values are calculated with non-parametric Kruskal-Wallis for comparison between all four groups. Two-way comparison of HCV/HIV coinfection group with HCV or HIV monoinfection group was made using non-parametric Mann-Whitney $U$ and corrected for multiple comparisons. (B) Relative frequencies of cells expressing PD-1 in FoxP3+CD4 T cells and FoxP3-CD4T cells are compared in a representative FACS overlay on the left panel (FoxP3+CD4 T cells as red dot plot, FoxP3-CD4 T cells in blue density plot) and in pair-wise comparison in $10 \mathrm{HCV}, 9 \mathrm{HCV} / \mathrm{HIV}, 10 \mathrm{HIV}$, and 10 seronegative control. $P$-value is calculated by paired $t$-test.

Supplementary Material) but not with CD4 $\mathrm{T}$ cell frequency or co-stimulatory receptor expression on CD4 and CD8 T cells (data not shown). We also did not find an association between HIV viral load and FoxP3+ Treg frequency. For example, FoxP3+ Treg frequency did not differ between HIV-seropositive patients with and without active HIV viremia (Figure S2C in Supplementary Material, left panel). Furthermore, FoxP3+ Treg frequency did not correlate with HIV viral load among actively HIV-viremic patients (Figure S2C in Supplementary Material, middle panel), and it remained higher in HCV/HIV-coinfected patients with undetectable HIV viremia compared to HIVmonoinfected patients with undetectable HIV viremia and HCVmonoinfected patients (Figure S2C in Supplementary Material, right panel).

\section{VIRUS-SPECIFIC EFFECTOR T CELL RESPONSES IN HCV/HIV-COINFECTED PATIENTS DO NOT CORRELATE WITH FOXP3+ Treg FREOUENCY OR IMMUNE INHIBITORY RECEPTOR EXPRESSION LEVELS ON T CELLS}

Effector T cell responses to HCV NS3, HIV Gag, and influenza matrix peptides were compared between the patient groups with IFN $\gamma$ Elispot ex vivo (Figure 5A) and with short term in vitro 
A

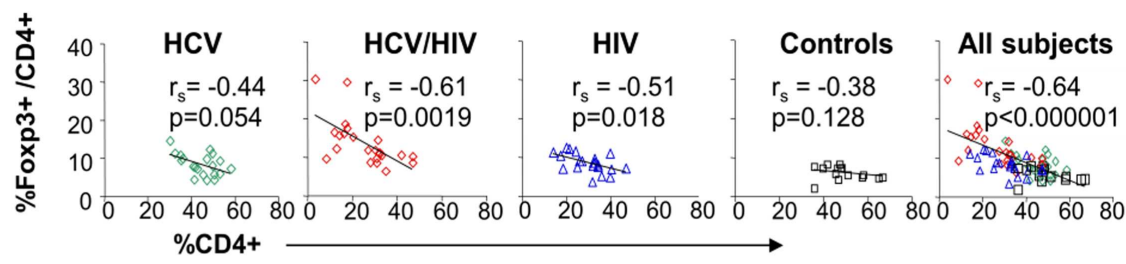

B

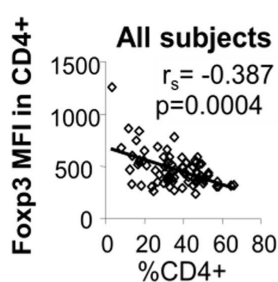

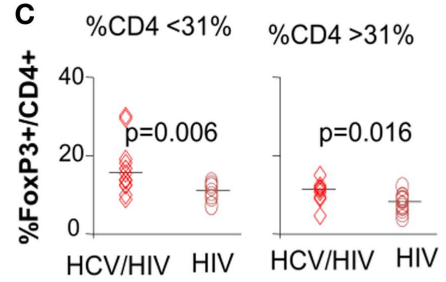

E
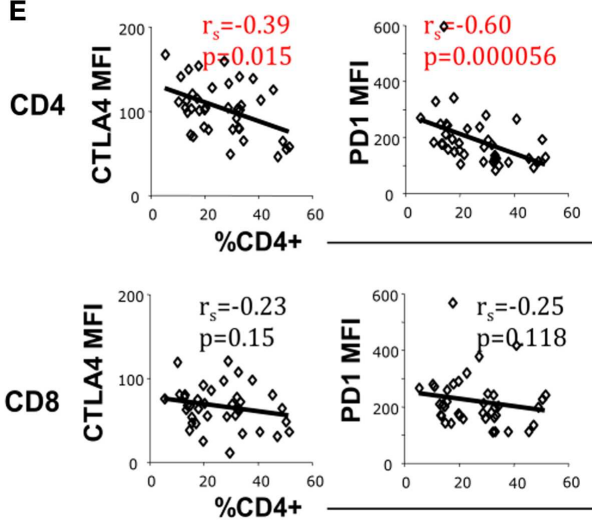
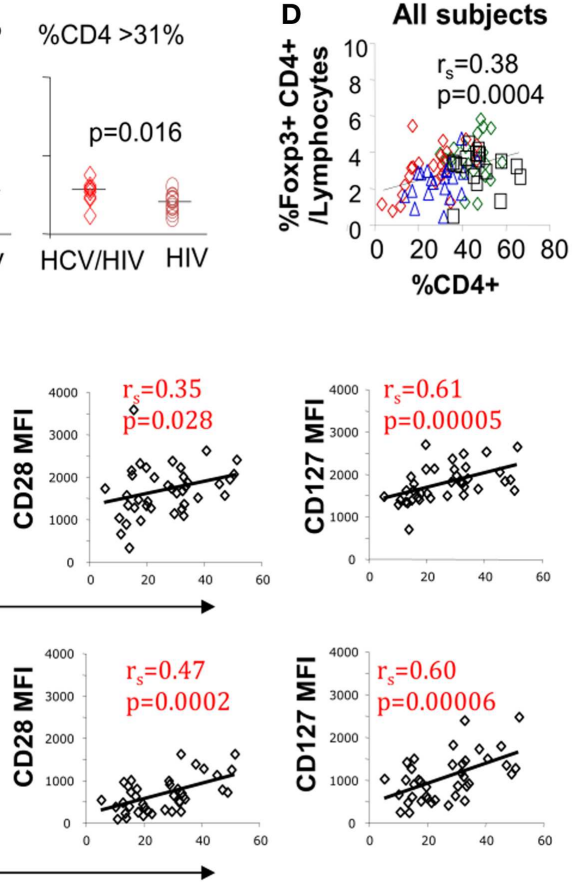

FIGURE 4 | Circulating CD4 T cell frequency is associated with FoxP3, PD-1, CTLA-4, and CD28 expression on T cell subsets. (A) Frequency of FoxP3+ Tregs in CD4 T cell compartment is compared with overall CD4 T cell frequency in live lymphocytes for each patient group and with all groups combined with $20 \mathrm{HCV}$-monoinfected (HCV), $23 \mathrm{HCV} / \mathrm{HIV}$-coinfected (HCV/HIV), 21 HIV-monoinfected (HIV), and 17 seronegative control (NC) subjects. Spearman rank-order correlation and $P$-values are shown.

(B) FoxP3 mean fluorescence intensity (MFI) is compared with overall CD4 $T$ cell frequency in live lymphocytes. Spearman rank-order correlation and $P$-values are shown. (C) Frequency of FoxP3+ Tregs in CD4 T cell compartment is compared between in HCV/HIV-coinfected and HIV-monoinfected patients with CD4 T cell frequency below or higher than a cutoff of $31 \%$ (median CD4T cell frequency). $P$-values are calculated by non-parametric Mann-Whitney $U$ test. (D) Frequency of FoxP3+CD4+ T cells in live lymphocyte compartment is compared with CD4 T cell frequency with Spearman rank-order correlation and $P$-values. (E) CTLA-4, PD-1, CD28, and CD127 mean fluorescence intensities (MFI) in CD4 and CD8 T cells are compared with overall CD4T cell frequency in live lymphocyte compartment. Spearman rank-order correlation and $P$-values are shown. culture followed by intracellular cytokine staining (Figures 5B,C). In general, $\mathrm{T}$ cell response to $\mathrm{HCV}$ was weak in $\mathrm{HCV}$-infected patients, whereas $\mathrm{T}$ cell response to HIV was more readily detected in HIV-infected patients (Figures 5A,B). In particular, HCV/HIVcoinfected patients displayed weak to undetectable T cell IFN $\gamma$ response to HCV that contrasted with HIV-specific T cell IFN $\gamma$ responses that were readily detected at levels similar to HIVmonoinfected patients (Figures 5A-C). Relevant for immune regulatory pathways, T cell IFN $\gamma$ responses to HCV, HIV, or influenza peptides did not correlate with FoxP3 + Treg frequency (Figure 5D) or T cell expression of PD-1 or CTLA-4 (data not shown).

We then examined if blockade of PD- 1 and/or CTLA- 4 with anti-PDL1 and anti-CTLA- 4 could enhance virus-specific effector $\mathrm{T}$ cell responses in $11 \mathrm{HCV} / \mathrm{HIV}$-coinfected patients. As shown in Figures 6A-C, anti-PD-1 augmented HIV-specific CD8
$\mathrm{T}$ cell response in 3/11 patients and HIV-specific CD4 $\mathrm{T}$ cell response in 5/11 patients. By contrast, PD-1 blockade augmented $\mathrm{HCV}$-specific CD8 $\mathrm{T}$ cell responses in 0/11 patients and HCVspecific CD4 $\mathrm{T}$ cell response in $1 / 11$ patients. This resulted in anti-PDL1-mediated augmentations for 8/22 HIV-specific T cell responses and $1 / 22 \mathrm{HCV}$-specific $\mathrm{T}$ cell response (36 vs. $4.5 \%$, $P=0.02)$. As for CTLA-4 blockade, there was no augmentation for HCV-specific T cell responses compared to $3 / 22 \mathrm{HIV}$-specific $\mathrm{T}$ cell responses ( 0 vs. $14 \%, P=\mathrm{NS}$ ). Augmentations were also observed for Flu-specific CD4 T cell response upon CTLA-4 but not PD-1 blockade. Combined PD-1/CTLA-4 blockade did not further enhance antiviral $\mathrm{T}$ cell function (data not shown), consistent with our previous study regarding peripheral blood compartment $(6,7)$.

Collectively, we show that multiple immune regulatory pathways are induced in HCV/HIV coinfection including FoxP+ Tregs, 
A

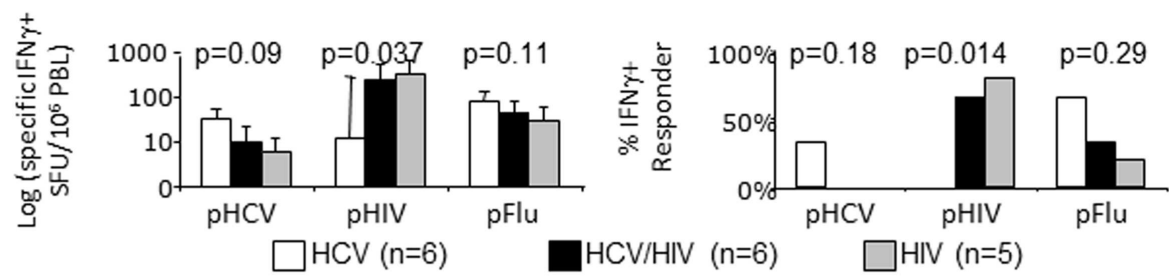

B
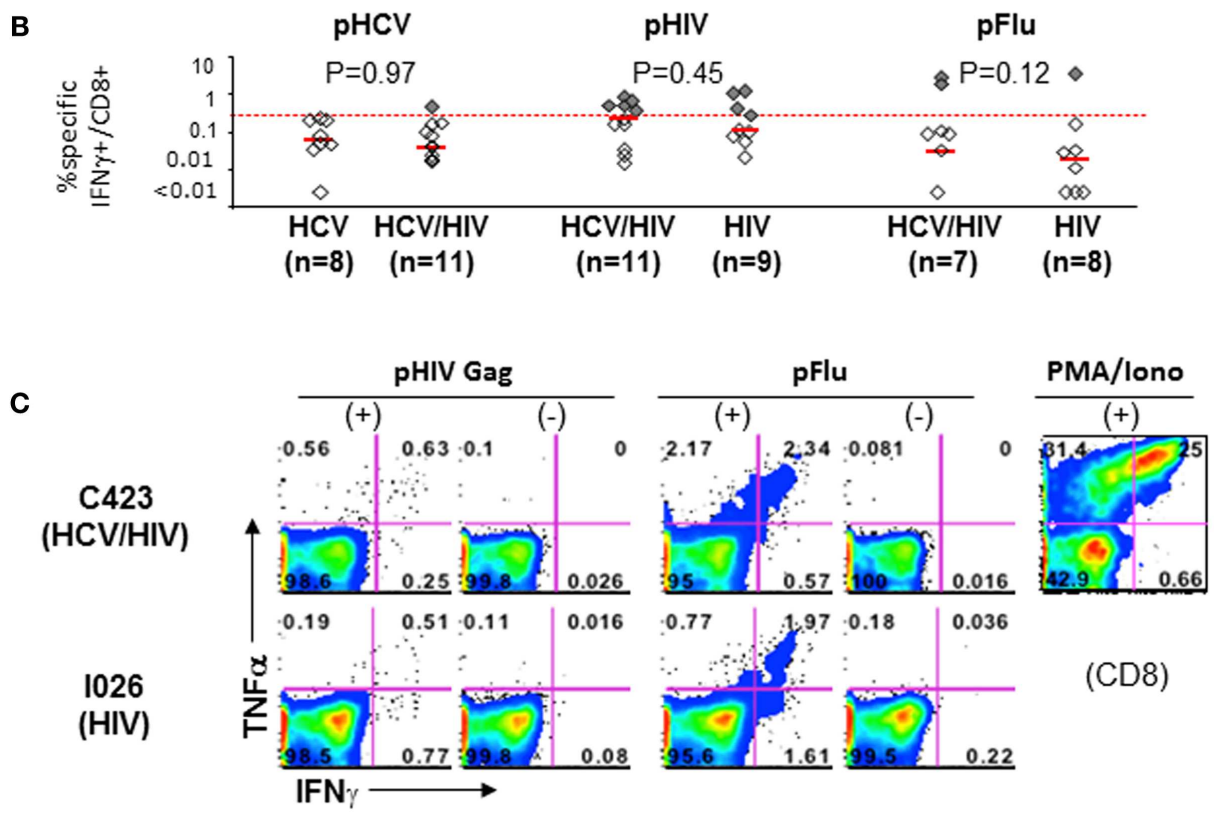

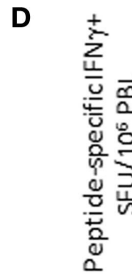
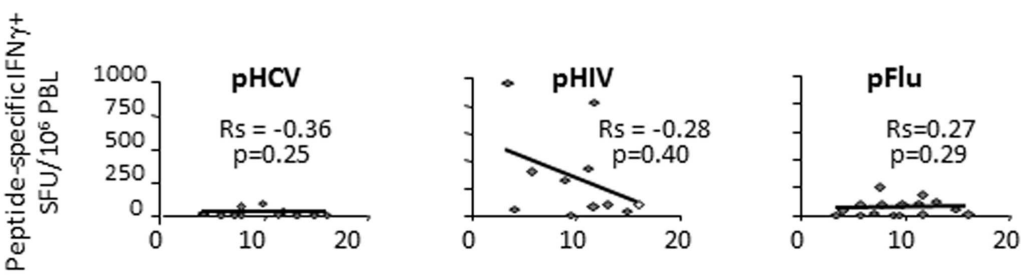

$\%$ FoxP3+/CD4 T cells

FIGURE 5 |T cell cytokine responses to HCV, HIV, and Flu peptides.

(A) Median T cell IFN $\gamma$ responses and percent positive responders to $\mathrm{HCV}$, HIV, and Flu peptides in HCV, HCV/HIV, and HIV-infected patient groups are shown in log scale (log spot forming units per million PBMC) based on IFN $\gamma$ ELISPOT assay using PBMCs stimulated ex vivo with overlapping $15 \mathrm{mer}$ peptide pools spanning HCV NS3 (pHCV), HIV Gag (pHIV), and influenza matrix (pFlu). Unfilled bar (HCV-monoinfected, $n=6$ ), black bar (HCV/HIV-coinfected, $n=6$ ), gray bar (HIV-monoinfected, $n=5$ ). Positive responses were defined by cutoff values for each assay (>average background $+3 \mathrm{SDs}$ ). $P$-values comparing three groups were calculated by non-parametric Kruskal-Wallis with only significant difference seen for HIV-specific T cell response (both by SFU and \% responders) due to lack of HIV-specific T cell response in HCV-monoinfected patients. (B) Frequency of $\mathrm{CD} 8+\mathrm{T}$ cells with antigen-specific IFN $\gamma$ production in short term PBMC cultures is shown from HCV/HIV-coinfected patients, HCV-monoinfected, and HIV-monoinfected patients. PBMC cultures were stimulated for 7 days with overlapping peptide pools $(2 \mu \mathrm{M})$ and $\mathrm{rlL}-2$ followed by further $5.5 \mathrm{~h}$ peptide stimulation in the presence of Brefeldin A, intracellular cytokine staining, and FACS analysis. Total of $8 \mathrm{HCV} / \mathrm{HIV}$-coinfected patients, 11 HCV-monoinfected, and 9 HIV-monoinfected patients were included, with sample size for each stimulation condition shown as defined by available lymphocytes. Red dotted line indicates the $0.27 \%$, which was the cutoff value for a positive response based on average background +3 SDs. Positive responses above $0.27 \%$ are further highlighted as dark shaded diamonds. $P$-values comparing two groups were calculated by non-parametric Mann-Whitney $U$ without significant differences between the groups. (C) Representative FACS plots show TNF $\alpha$ and IFN $\gamma$ expression in CD8-gated cells from an HCV/HIV-coinfected (C423) and HIV-monoinfected (I026) subjects. (D) Peptide-specific IFN $\gamma$ response (in spot forming units per million PBMC) is compared with the frequency of FoxP3+ Tregs in CD4 T cell compartment from HCV/HIV-coinfected patients. Spearman rank-order correlation and $P$-values are shown without significant associations.
PD-1, and CTLA-4 in significant association with HIV-associated CD4 T cell loss and with apparent suppression of effector $\mathrm{T}$ cell responses against $\mathrm{HIV}$ but not $\mathrm{HCV}$.

\section{DISCUSSION}

Effector functions of virus-specific CD8 $\mathrm{T}$ cells are regulated by extrinsic immune regulatory pathways including Tregs and 
A

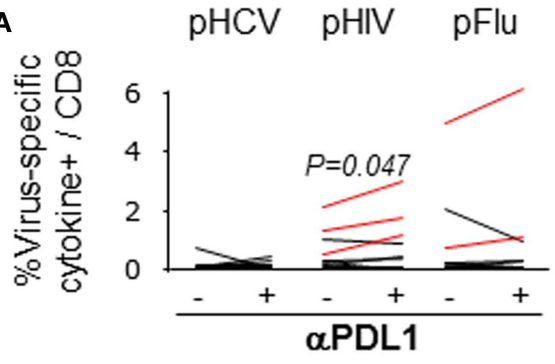

B

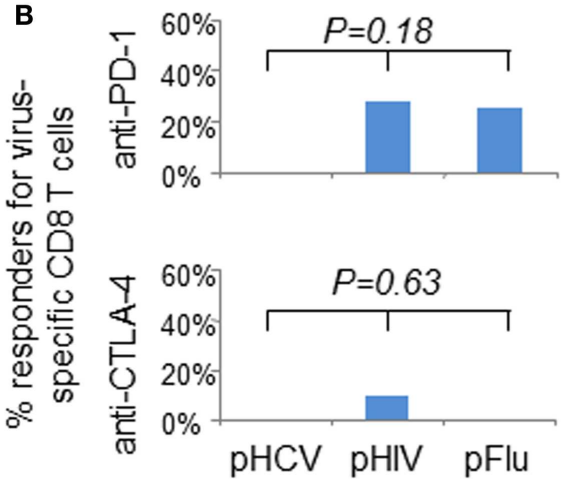

C

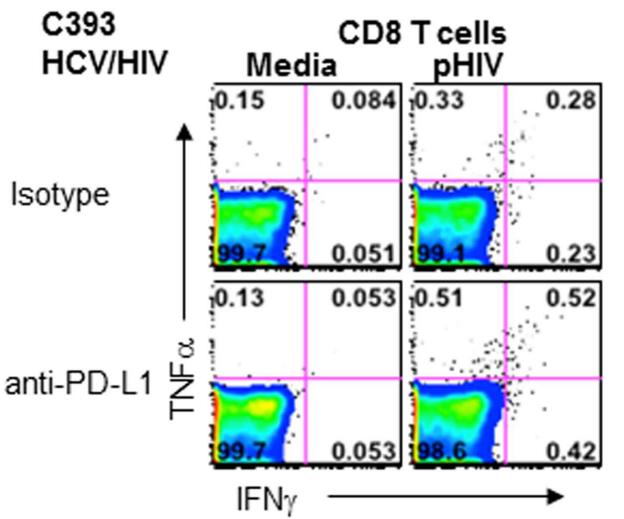

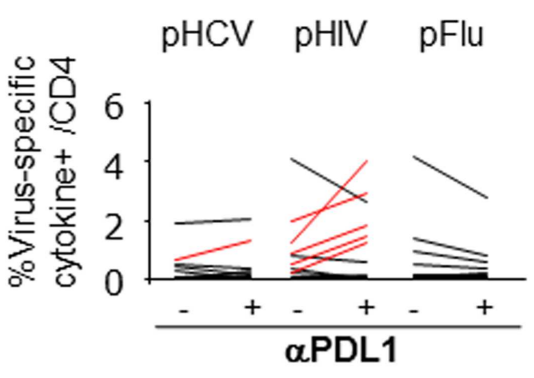

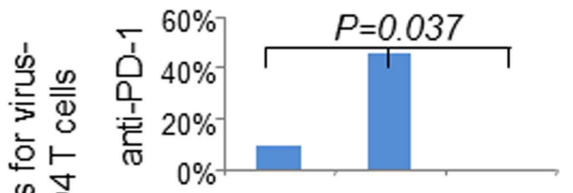

产吉 它

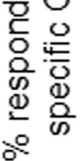

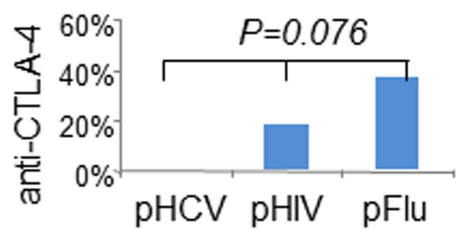

FIGURE 6 | Effect of in vitro PD-1 blockade on virus-specific T cell cytokine responses in $\mathrm{HCV} / \mathrm{HIV}$-coinfected patients. T cell cytokine responses (combining IFN $\gamma$ and/or TNF $\alpha$ responses) to HCV, HIV, and Flu peptides were examined in HCV/HIV-coinfected patients with and without PD-1 and/or CTLA-4 blockade in vitro. PBMCs from HCV/HIV-coinfected patients were cultured for 7 days in vitro with pHCV NS3, pHIV GAG, or pFlu Matrix in the presence of isotype control or blocking antibodies. The 7-day cultures were further stimulated for $6 \mathrm{~h}$ with media alone or with each peptide before intracellular IFN- $\gamma$ and TNF- $\alpha$ staining. Virus-specific responses were calculated by subtracting the cytokine responses in media control samples from peptide-stimulated samples during the intracellular cytokine staining. A positive response to blockade was defined as antigen-specific response that was greater than the isotype control condition by at least a standard deviation of the all background responses $(0.36 \%)$. (A) Percentage of virus-specific cytokine+ cells in CD8 (left panel) and CD4T cells (right panel) are shown from
HCV/HIV-coinfected patients, comparing responses with isotype antibody and with anti-PDL1 blocking Ab $(10 \mu \mathrm{g} / \mathrm{ml})$. Significant $P$-value per paired $t$-test is shown for HIV Gag. Assay pairs with augmented responses to PD-1 blockade above isotype control condition are highlighted as red lines. Significant increase in cytokine response by PD-1 blockade is shown for HIV-specific CD8 T cells $(P=0.047)$ via paired $t$-test. $(\mathbf{B})$ Percentage of positive responders (augmentations above $0.36 \%$ ) to anti-PDL1 or anti-CTLA-4 is shown for virus-specific CD8 (left panel) and CD4 T cells (right panel) from $\mathrm{HCV} / \mathrm{HIV}$-coinfected patients. Significant anti-PDL1-mediated augmentation is shown for HIV-specific CD4 T cell response by Kruskal-Wallis $(P=0.037)$. (C) Representative FACS plots are shown for HIV Gag-specific IFN- $\gamma$ and TNF- $\alpha$ production in CD8 (left) and CD4 T cells (right) in short term PBMC culture from HCV/HIV-coinfected patients, following 7 day culture with HIV peptides in the presence of either isotype antibody or anti-PDL1. Marked induction in IFN $\gamma$ and TNF $\alpha$ responses is apparent for CD4T cells following PD-1 blockade. cytokines as well as intrinsic expression of immune modulatory molecules $(9,42-45)$. In viral infections, these regulatory pathways can limit the extent of cellular injury but also promote viral survival with long-term pathogenetic consequences. In particular,
$\mathrm{HCV}$ persists with functionally impaired $\mathrm{HCV}$-specific effector $\mathrm{T}$ cells that over-express PD-1, CTLA-4, and/or Tim-3 (6, 7, 45-47) and increased circulating FoxP3 + Tregs that are indistinguishable from natural Tregs $(33,36,48,49)$. Treg development and 
function may in turn be influenced by PD-1 and CD28 $(17,50)$. Further complexity is expected in HCV/HIV coinfection due to HIV-mediated immune effects as well as Treg dynamics $(23,51)$. For example, PD-1 and CTLA-4 expression in antiviral T cells correlated with HIV viral load and CD4 T cell count in HIVmonoinfected patients (3-5). With HCV/HIV coinfection, Treg induction has been related to $\operatorname{HIV}$ rather than $\operatorname{HCV}(24,30)$ whereas PD-1/Tim-3 co-expression in both total and HCV-specific $\mathrm{T}$ cells associated with liver-related outcomes (52). In this study, the interplay between Tregs and intrinsic co-stimulatory pathways in HCV/HIV coinfection was examined with the hypothesis that HCV/HIV coinfection will heighten immune dysregulation associated with chronic viral infection.

In fact, FoxP3 + Treg frequency in total lymphocytes was similar between HCV/HIV-coinfected and HCV-monoinfected patients despite almost twofold difference in $\mathrm{CD} 4 \mathrm{~T}$ cell frequency between HCV/HIV-coinfected and HCV-monoinfected patients. This was due to significantly enriched FoxP3 expression in CD4 T cells from HCV/HIV-coinfected patients compared to other groups. Increased FoxP3 expression in CD4 T cells from HCV/HIVcoinfected patients was not due to active HIV viremia since most patients (83\%) had HIV viral load below detection limit. FoxP3+ Tregs from HCV/HIV-coinfected patients generally resembled natural Tregs in phenotype and suppressive function (Figure 1). However, FoxP3 + Tregs from HCV/HIV-coinfected patients (as well as HIV-monoinfected patients) displayed increased PD-1 expression compared to Tregs from HIV-uninfected subjects, suggesting that HIV-mediated immune activation extends to FoxP3+ Tregs.

Perhaps due to the preserved FoxP3+ Treg frequency in total lymphocytes, there was no significant association between FoxP3+ Treg frequency and HCV-associated liver disease parameters or HCV RNA titers. However, FoxP3 expression in CD4 T cells was inversely correlated with overall $\mathrm{CD} 4 \mathrm{~T}$ cell frequency, a critical marker of immune competence. While this inverse association was previously reported in HIV-monoinfected patients (23), our study further extends this association to HCV/HIVcoinfected patients. Perhaps more interestingly, the inverse association between $\mathrm{CD} 4 \mathrm{~T}$ cell frequency and FoxP3 + Treg frequency became even stronger when all subjects (including the uninfected controls) were included ( $\mathrm{rs}=-0.64, P<0.000001)$. This suggested a more generalized homeostatic mechanism to sustain FoxP3+ Treg frequency as CD4 T cell frequency declines. This possibility was previously reported for cancer patients undergoing chemotherapy (53), but may be more generalized based on our findings. In this regard, HIV-mediated CD4 $\mathrm{T}$ cell loss may play a dominant effect on FoxP3+ Treg dynamics to preserve the total circulating FoxP3+ Tregs $(24,30)$, although this is insufficient with progressive HIV-associated CD4 T cell loss.

The main finding in our study is that multiple immune inhibitory pathways are induced HCV/HIV-coinfected patients due to HCV and/or HIV infection, despite therapeutic HIV suppression. At the same time, both CD4 and CD8 T cells in HCV/HIV-coinfected patients showed reduced expression of positive co-stimulatory receptor CD28 and IL7 receptor alpha CD127. FoxP3+ Treg frequency correlated with expression of PD-1 and CTLA-4 on CD4 T cells as well as CTLA-4 and CD28 expression on CD8 T cells. These associations are likely linked to CD4
$\mathrm{T}$ cell frequency in which CD4 T cell loss occurs with preferential induction of multiple inhibitory pathways in CD4 (but not CD8) $\mathrm{T}$ cells and reduction in $\mathrm{CD} 28$ and $\mathrm{CD} 127$ expression for both CD4 and CD8 T cells. It is not clear if these changes are the cause or consequence of CD4 T cell loss. Furthermore, immune inhibitory induction despite apparent therapeutic HIV suppression suggests that virus control is not absolute and that there is ongoing HIV-associated immune activation.

Blockade of one or more co-stimulatory receptor including PD-1, CTLA-4, Tim-3, and 4-1BB has been shown to enhance virus-specific $\mathrm{T}$ cell function in chronic viral infections including HCV, HBV, HIV, and SIV (2-12,31). Better understanding of these pathways has therapeutic implications, given the available agents to modulate these pathways to treat chronic viral infection and enhance tumor immunity. For example, PD-1 blockade in vivo improved control of SIV in vivo with enhanced gut immunity, reduced microbial translocation, and survival of SIV-infected rhesus macaques $(11,12)$. Furthermore, PD-1 blockade in vivo was well-tolerated and promoted virus control in a subset of HCVinfected patients (54) whereas CTLA-4 blockade in patients with hepatocellular carcinoma and chronic hepatitis $\mathrm{C}$ was tolerated with antiviral and immune stimulatory effects (32). Our findings in HCV/HIV-coinfected patients show that co-stimulatory receptor blockade was more effective for $\mathrm{T}$ cell responses to HIV than HCV. This may in part reflect the underlying frequency as well as functionality of HCV-specific T cells. Since most HCV/HIVcoinfected patients in our study had therapeutic suppression of HIV (but not HCV), HIV-specific T cells may have been less exhausted and paradoxically more responsive to co-stimulatory blockade than HCV-specific T cells. In this regard, we previously showed that PD-1 blockade was less effective for highly exhausted HCV-specific T cells isolated from HCV-infected liver $(6,7)$. Alternatively, $\mathrm{HCV}$-specific effector T cells may be poorly maintained in HCV/HIV-coinfected patients due to HIV-associated CD4 T cell dysfunction and immune inhibition. It is also possible that $\mathrm{HCV}$ and HIV reside in different compartments although we previously showed that in vitro PD-1 blockade of PBMC can enhance HCVspecific effector $\mathrm{T}$ cell function in four/six HCV-infected patients (6).

Collectively, we show that multiple $\mathrm{T}$ cell inhibitory pathways are induced in patients with HCV/HIV coinfection. These changes were inversely associated with circulating $\mathrm{CD} 4 \mathrm{~T}$ cell frequencies as a consequence of HIV infection, but not with viral titers or $\mathrm{HCV}$-associated liver function parameters. In vitro $\mathrm{PD}-1$ blockade of PBMC from HCV/HIV-coinfected patients restored effector T cell responses to HIV but not HCV with less prominent impact by CTLA-4 blockade. These findings provide new insights on interplay between extrinsic and intrinsic immune regulatory pathways as well as virus-specific effect of co-stimulatory receptor blockade relevant for immunotherapeutic development.

\section{ACKNOWLEDGMENTS}

This material is based upon work supported in part by the Office of Research and Development, Department of Veterans Affairs and with the resources, and the use of facilities at the Philadelphia VA Medical Center. This study was also supported by NIH Grants R01-AI-47519, R01-AA-12849; The W. W. Smith Charitable Trust 
funding; The AGA Fiterman Basic Research Award; the Philadelphia VA Medical Research; NIH/NIDDK Center of Molecular Studies in Digestive and Liver Diseases P30DK50306 and its Molecular Biology and Cell Culture Core Facilities; the NIH Public Health Service Research Grant M01-RR00040. Hyosun Cho was supported in part by the NIH: 8538300 Tumor Virology Training Grant at the University of Pennsylvania. The contents of this work do not represent the views of the Department of Veterans Affairs or the United States Government.

\section{SUPPLEMENTARY MATERIAL}

The Supplementary Material for this article can be found online at http://www.frontiersin.org/Journal/10.3389/fimmu.2014.00265/ abstract

\section{REFERENCES}

1. Barber DL, Wherry EJ, Masopust D, Zhu B, Allison JP, Sharpe AH, et al. Restoring function in exhausted CD8 T cells during chronic viral infection. Nature (2006) 439:682-7. doi:10.1038/nature04444

2. Freeman GJ, Wherry EJ, Ahmed R, Sharpe AH. Reinvigorating exhausted HIVspecific T cells via PD-1-PD-1 ligand blockade. J Exp Med (2006) 203:2223-7. doi:10.1084/jem.20061800

3. Day CL, Kaufmann DE, Kiepiela P, Brown JA, Moodley ES, Reddy S, et al. PD1 expression on HIV-specific T cells is associated with T-cell exhaustion and disease progression. Nature (2006) 443:350-4. doi:10.1038/nature05115

4. Kaufmann DE, Walker BD. Programmed death-1 as a factor in immune exhaustion and activation in HIV infection. Curr Opin HIV AIDS (2008) 3:362-7. doi:10.1097/COH.0b013e3282f9ae8b

5. Kaufmann DE, Kavanagh DG, Pereyra F, Zaunders JJ, Mackey EW, Miura T, et al. Upregulation of CTLA- 4 by HIV-specific CD4 $(+)$ T cells correlates with disease progression and defines a reversible immune dysfunction. Nat Immunol (2007) 8:1246-54. doi:10.1038/ni1515

6. Nakamoto N, Kaplan DE, Coleclough J, Li Y, Valiga ME, Kaminski M, et al. Functional restoration of HCV-specific CD8 T cells by PD-1 blockade is defined by PD-1 expression and compartmentalization. Gastroenterology (2008) 134:1937.e1-2. doi:10.1053/j.gastro.2008.02.033

7. Nakamoto N, Cho H, Shaked A, Olthoff K, Valiga ME, Kaminski M, et al. Synergistic reversal of intrahepatic HCV-specific CD8 T cell exhaustion by combined PD-1/CTLA-4 blockade. PLoS Pathog (2009) 5:e1000313. doi:10.1371/journal. ppat. 1000313

8. Tzeng HT, Tsai HF, Liao HJ, Lin YJ, Chen L, Chen PJ, et al. PD-1 blockage reverses immune dysfunction and hepatitis B viral persistence in a mouse animal model. PLoS One (2012) 7:e39179. doi:10.1371/journal.pone.0039179

9. Fisicaro P, Valdatta C, Massari M, Loggi E, Ravanetti L, Urbani S, et al. Combined blockade of programmed death-1 and activation of CD137 increase responses of human liver T cells against HBV, but not HCV. Gastroenterology (2012) 143(6):1576-85.e4. doi:10.1053/j.gastro.2012.08.041

10. Boni C, Fisicaro P, Valdatta C, Amadei B, Di Vincenzo P, Giuberti T, et al. Characterization of hepatitis $\mathrm{B}$ virus (HBV)-specific T-cell dysfunction in chronic HBV infection. J Virol (2007) 81:4215-25. doi:10.1128/JVI.02844-06

11. Dyavar Shetty R, Velu V, Titanji K, Bosinger SE, Freeman GJ, Silvestri G, et al. PD1 blockade during chronic SIV infection reduces hyperimmune activation and microbial translocation in rhesus macaques. J Clin Invest (2012) 122:1712-6. doi:10.1172/JCI60612

12. Estes JD. Enhancing immune responses to limit chronic immune activation during SIV. J Clin Invest (2012) 122:1611-4. doi:10.1172/JCI63389

13. Anderson KB, Guest JL, Rimland D. Hepatitis C virus coinfection increases mortality in HIV-infected patients in the highly active antiretroviral therapy era: data from the HIV Atlanta VA Cohort Study. Clin Infect Dis (2004) 39:1507-13. doi:10.1086/425360

14. Merriman NA, Porter SB, Brensinger CM, Reddy KR, Chang KM. Racial difference in mortality among U.S. veterans with HCV/HIV coinfection. Am J Gastroenterol (2006) 101(4):760-7. doi:10.1111/j.1572-0241.2006.00531.x

15. Wan YY. Regulatory T cells: immune suppression and beyond. Cell Mol Immunol (2010) 7:204-10. doi:10.1038/cmi.2010.20
16. Fife BT, Bluestone JA. Control of peripheral T-cell tolerance and autoimmunity via the CTLA-4 and PD-1 pathways. Immunol Rev (2008) 224:166-82. doi:10.1111/j.1600-065X.2008.00662.x

17. Zhang R, Huynh A, Whitcher G, Chang J, Maltzman JS, Turka LA. An obligate cell-intrinsic function for CD28 in Tregs. J Clin Invest (2013) 123:580-93. doi:10.1172/JCI65013

18. Sage PT, Francisco LM, Carman CV, Sharpe AH. The receptor PD-1 controls follicular regulatory T cells in the lymph nodes and blood. Nat Immunol (2013) 14:152-61. doi:10.1038/ni.2496

19. Kaufmann DE, Walker BD. PD-1 and CTLA-4 inhibitory cosignaling pathways in HIV infection and the potential for therapeutic intervention. J Immunol (2009) 182:5891-7. doi:10.4049/jimmunol.0803771

20. Elrefaei M, Baker CA, Jones NG, Bangsberg DR, Cao H. Presence of suppressor HIV-specific CD8 + T cells is associated with increased PD-1 expression on effector CD8+ T cells. J Immunol (2008) 180:7757-63. doi:10.4049/jimmunol. 180.11 .7757

21. Bi X, Suzuki Y, Gatanaga H, Oka S. High frequency and proliferation of CD4+ FOXP3+ Treg in HIV-1-infected patients with low CD4 counts. Eur J Immunol (2009) 39:301-9. doi:10.1002/eji.200838667

22. Cao W, Jamieson BD, Hultin LE, Hultin PM, Detels R. Regulatory T cell expansion and immune activation during untreated HIV type 1 infection are associated with disease progression. AIDS Res Hum Retroviruses (2009) 25:183-91. doi:10.1089/aid.2008.0140

23. Schulze Zur Wiesch J, Thomssen A, Hartjen P, Toth I, Lehmann C, MeyerOlson D, et al. Comprehensive analysis of frequency and phenotype of $\mathrm{T}$ regulatory cells in HIV infection: CD39 expression of FoxP3 + T regulatory cells correlates with progressive disease. J Virol (2011) 85:1287-97. doi:10.1128/JVI. 01758-10

24. Rallon NI, Lopez M, Soriano V, Garcia-Samaniego J, Romero M, Labarga P, et al. Level, phenotype and activation status of CD4+FoxP3 + regulatory T cells in patients chronically infected with human immunodeficiency virus and/or hepatitis C virus. Clin Exp Immunol (2009) 155:35-43. doi:10.1111/j.1365-2249. 2008.03797.x

25. Suchard MS, Mayne E, Green VA, Shalekoff S, Donninger SL, Stevens WS, et al. FOXP3 expression is upregulated in CD4T cells in progressive HIV1 infection and is a marker of disease severity. PLoS One (2010) 5:e11762. doi:10.1371/journal.pone.0011762

26. Prendergast A, Prado JG, Kang YH, Chen F, Riddell LA, Luzzi G, et al. HIV-1 infection is characterized by profound depletion of CD161+ Th17 cells and gradual decline in regulatory T cells. AIDS (2010) 24:491-502. doi:10.1097/ QAD.0b013e3283344895

27. Apoil PA, Puissant B, Roubinet F, Abbal M, Massip P, Blancher A. FOXP3 mRNA levels are decreased in peripheral blood CD4+ lymphocytes from HIV-positive patients. J Acquir Immune Defic Syndr (2005) 39:381-5. doi:10.1097/01.qai. $0000169662.30783 .2 \mathrm{~d}$

28. Sachdeva M, Fischl MA, Pahwa R, Sachdeva N, Pahwa S. Immune exhaustion occurs concomitantly with immune activation and decrease in regulatory $\mathrm{T}$ cells in viremic chronically HIV-1-infected patients. J Acquir Immune Defic Syndr (2010) 54:447-54. doi:10.1097/QAI.0b013e3181e0c7d0

29. Epple HJ, Loddenkemper C, Kunkel D, Troger H, Maul J, Moos V, et al. Mucosal but not peripheral FOXP3 + regulatory $\mathrm{T}$ cells are highly increased in untreated HIV infection and normalize after suppressive HAART. Blood (2006) 108:3072-8. doi:10.1182/blood-2006-04-016923

30. Zhuang Y, Wei X, Li Y, Zhao K, Zhang J, Kang W, et al. HCV coinfection does not alter the frequency of regulatory $\mathrm{T}$ cells or $\mathrm{CD} 8+\mathrm{T}$ cell immune activation in chronically infected HIV + Chinese subjects. AIDS Res Hum Retroviruses (2012) 28:1044-51. doi:10.1089/AID.2011.0318

31. Schurich A, Khanna P, Lopes AR, Han KJ, Peppa D, Micco L, et al. Role of the coinhibitory receptor cytotoxic $\mathrm{T}$ lymphocyte antigen-4 on apoptosisProne CD8 T cells in persistent hepatitis B virus infection. Hepatology (2011) 53:1494-503. doi:10.1002/hep.24249

32. Sangro B, Gomez-Martin C, de la Mata M, Inarrairaegui M, Garralda E, Barrera $\mathrm{P}$, et al. A clinical trial of CTLA-4 blockade with tremelimumab in patients with hepatocellular carcinoma and chronic hepatitis C. J Hepatol (2013) 59:81-8. doi:10.1016/j.jhep.2013.02.022

33. Sugimoto K, Ikeda F, Stadanlick J, Nunes FA, Alter HJ, Chang KM. Suppression of HCV-specific T cells without differential hierarchy demonstrated ex vivo in persistent HCV infection. Hepatology (2003) 38:1437-48. doi:10.1053/jhep. 2003.09026 
34. Sugimoto K, Kaplan DE, Ikeda F, Ding J, Schwartz J, Nunes FA, et al. Strainspecific T-cell suppression and protective immunity in patients with chronic hepatitis C virus infection. J Virol (2005) 79:6976-83. doi:10.1128/JVI.79.11. 6976-6983.2005

35. Ferre AL, Lemongello D, Hunt PW, Morris MM, Garcia JC, Pollard RB, et al. Immunodominant HIV-specific CD8+ T-cell responses are common to blood and gastrointestinal mucosa, and Gag-specific responses dominate in rectal mucosa of HIV controllers. J Virol (2010) 84:10354-65. doi:10.1128/JVI. 00803-10

36. Ebinuma H, Nakamoto N, Li Y, Price DA, Gostick E, Levine BL, et al. Identification and in vitro expansion of functional antigen-specific CD25+ FoxP3+ regulatory $\mathrm{T}$ cells in hepatitis $\mathrm{C}$ virus infection. J Virol (2008) 82:5043-53. doi:10.1128/JVI.01548-07

37. Kaplan DE, Sugimoto K, Newton K, Valiga ME, Ikeda F, Aytaman A, et al. Discordant role of CD4 $\mathrm{T}$-cell response relative to neutralizing antibody and CD8 T-cell responses in acute hepatitis C. Gastroenterology (2007) 132:654-66. doi:10.1053/j.gastro.2006.11.044

38. Gregg R, Smith CM, Clark FJ, Dunnion D, Khan N, Chakraverty R, et al. The number of human peripheral blood CD4+ CD25high regulatory $\mathrm{T}$ cells increases with age. Clin Exp Immunol (2005) 140:540-6. doi:10.1111/j.13652249.2005.02798.x

39. Rosenkranz D, Weyer S, Tolosa E, Gaenslen A, Berg D, Leyhe T, et al. Higher frequency of regulatory $\mathrm{T}$ cells in the elderly and increased suppressive activity in neurodegeneration. J Neuroimmunol (2007) 188:117-27. doi:10.1016/j. jneuroim.2007.05.011

40. Lages CS, Suffia I, Velilla PA, Huang B, Warshaw G, Hildeman DA, et al. Functional regulatory $\mathrm{T}$ cells accumulate in aged hosts and promote chronic infectious disease reactivation. J Immunol (2008) 181:1835-48. doi:10.4049/ jimmunol.181.3.1835

41. Jagger A, Shimojima Y, Goronzy JJ, Weyand CM. Regulatory T cells and the immune aging process: a mini-review. Gerontology (2014) 60(2):130-7. doi:10.1159/000355303

42. Wherry EJ. T cell exhaustion. Nat Immunol (2011) 12:492-9.

43. Chevalier MF, Weiss L. The split personality of regulatory T cells in HIV infection. Blood (2013) 121(1):29-37. doi:10.1182/blood-2012-07-409755

44. Virgin HW, Wherry EJ, Ahmed R. Redefining chronic viral infection. Cell (2009) 138:30-50. doi:10.1016/j.cell.2009.06.036

45. Golden-Mason L, Palmer BE, Kassam N, Townshend-Bulson L, Livingston S, McMahon BJ, et al. Negative immune regulator Tim-3 is overexpressed on $\mathrm{T}$ cells in hepatitis $\mathrm{C}$ virus infection and its blockade rescues dysfunctional CD4+ and CD8+ T cells. J Virol (2009) 83:9122-30. doi:10.1128/JVI.00639-09

46. Radziewicz H, Ibegbu CC, Fernandez ML, Workowski KA, Obideen K, Wehbi M, et al. Liver-infiltrating lymphocytes in chronic human hepatitis $\mathrm{C}$ virus infection display an exhausted phenotype with high levels of PD-1 and low levels of CD127 expression. J Virol (2007) 81:2545-53. doi:10.1128/JVI.02021-06

47. McMahan RH, Golden-Mason L, Nishimura MI, McMahon BJ, Kemper M, Allen TM, et al. Tim-3 expression on PD-1+ HCV-specific human CTLs is associated with viral persistence, and its blockade restores hepatocyte-directed in vitro cytotoxicity. J Clin Invest (2010) 120:4546-57. doi:10.1172/JCI43127

48. Boettler T, Spangenberg HC, Neumann-Haefelin C, Panther E, Urbani S, Ferrari $\mathrm{C}$, et al. $\mathrm{T}$ cells with a $\mathrm{CD} 4+\mathrm{CD} 25+$ regulatory phenotype suppress in vitro proliferation of virus-specific CD8 $+\mathrm{T}$ cells during chronic hepatitis C virus infection. JVirol (2005) 79:7860-7. doi:10.1128/JVI.79.12.7860-7867. 2005

49. Cabrera R, Tu Z, Xu Y, Firpi RJ, Rosen HR, Liu C, et al. An immunomodulatory role for $\mathrm{CD} 4(+) \mathrm{CD} 25(+)$ regulatory $\mathrm{T}$ lymphocytes in hepatitis $\mathrm{C}$ virus infection. Hepatology (2004) 40:1062-71. doi:10.1002/hep.20454

50. Franceschini D, Paroli M, Francavilla V, Videtta M, Morrone S, Labbadia G, et al. PD-L1 negatively regulates CD4+CD25+Foxp3+ Tregs by limiting STAT5 phosphorylation in patients chronically infected with HCV. JClin Invest (2009) 119:551-64. doi:10.1172/JCI36604

51. Imamichi H, Lane HC. Regulatory T cells in HIV-1 infection: the good, the bad, and the ugly. J Infect Dis (2012) 205:1479-82. doi:10.1093/infdis/jis238

52. Vali B, Jones RB, Sakhdari A, Sheth PM, Clayton K, Yue FY, et al. HCV-specific T cells in HCV/HIV co-infection show elevated frequencies of dual Tim-3/PD-1 expression that correlate with liver disease progression. Eur J Immunol (2010) 40:2493-505. doi:10.1002/eji.201040340

53. Rech AJ, Mick R, Kaplan DE, Chang KM, Domchek SM, Vonderheide RH. Homeostasis of peripheral FoxP3(+) CD4 (+) regulatory T cells in patients with early and late stage breast cancer. Cancer Immunol Immunother (2010) 59:599-607. doi:10.1007/s00262-009-0780-x

54. Gardiner D, Lalezari J, Lawitz E, DiMicco M, Ghalib R, Reddy KR, et al. A randomized, double-blind, placebo-controlled assessment of BMS-936558, a fully human monoclonal antibody to programmed death-1 (PD-1), in patients with chronic hepatitis C virus infection. PLoS One (2013) 8:e63818. doi:10.1371/journal.pone.0063818

Conflict of Interest Statement: There is no financial conflict of interest. However, Kyong-Mi Chang has family member employed by Bristol Myers Squibb, which makes biologics related to immune inhibitory blockade.

Received: 09 April 2014; accepted: 23 May 2014; published online: 08 July 2014.

Citation: Cho H, Kikuchi M, Li Y, Nakamoto N, Amorosa VK, Valiga ME and Chang K-M (2014) Induction of multiple immune regulatory pathways with differential impact in HCV/HIV coinfection. Front. Immunol. 5:265. doi: 10.3389/fimmu.2014.00265

This article was submitted to $T$ Cell Biology, a section of the journal Frontiers in Immunology.

Copyright (c) 2014 Cho, Kikuchi, Li, Nakamoto, Amorosa, Valiga and Chang. This is an open-access article distributed under the terms of the Creative Commons Attribution License (CC BY). The use, distribution or reproduction in other forums is permitted, provided the original author(s) or licensor are credited and that the original publication in this journal is cited, in accordance with accepted academic practice. No use, distribution or reproduction is permitted which does not comply with these terms. 